\title{
META-ANALISIS: VALIDITAS DAN PRAKTIKALITAS MODUL IPA BERBASIS SAINTIFIK
}

\author{
Rikizaputra $^{1)}$, Festiyed ${ }^{2)}$, Yuni Adha ${ }^{3)}$, Yerimadesi ${ }^{4)}$ \\ ${ }^{1)}$ Program Studi Pendidikan Biologi, Universitas Lancang Kuning \\ ${ }^{233) 4)}$ Program Studi Pendidikan Biologi, Universitas Negeri Padang \\ Email $^{1)}$ : rikizaputra@unilak.ac.id \\ Email $^{2)}$ : festiyed@fmipa.unp.ac.id \\ Email $^{3)}$ :ahdayuni@fmipa.unp.ac.id \\ Email $^{4)}$ : yeri@fmipa.unp.ac.id
}

\begin{abstract}
ABSTRAK: Penelitian ini bertujuan untuk menganalisis tingkat validitas dan praktikalitas pengembangan modul IPA berbasis saintifik. Penelitian ini menggunakan metode meta analisis. Data dikumpulkan dengan acara mencari artikel jurnal dari internet. Sampel yang digunakan sebanyak 20 artikel terkait dengan pengembangan modul IPA berbasis saintifik. Hasil penelitian menemukan bahwa tingkat validitas pengembangan modul IPA berbasis saintifik pada aspaspek isi 0,86 kategori valid, apek penyajian 0,88 kategori valid, aspek bahasa 0,87 kategori valid, aspek grafic 0,86 kategori valid. Tingkat kepraktisan guru 0,86 kategori sangat tinggi dan praktikalitas aspek siswa 0,85 kategori tinggi. Modul IPA berbasis saintifik yang dikembangkan dapat dikategorikan sebagai valid dan praktis sehingga layak digunakan dalam proses pembelajaran IPA.
\end{abstract}

Kata kunci: Meta-analisis, saintifik, modul, pembelajaran IPA

ABSTRACK: This study aims to analyze the level of validity and practicality of scientific-based science-based module development. This study uses a meta-analysis method. Data was collected by searching for journal articles from the internet. The sample used was 20 articles related to the development of a scientific-based science module. The results of the study found that the level of validity of scientific-based science-based module development on content aspects was 0.86 valid categories, slick presentation 0.88 valid categories, language aspects 0.87 valid categories, graphic aspects 0.86 valid categories. The practicality level of the teacher was 0.86 in the very high category and the practicality of the student's aspect was 0.85 in the high category. The scientific-based science module developed can be categorized as valid and practical so that it is suitable for use in the science learning process.

Keywords: Meta-analysis, scientific, module, science learning

\section{PENDAHULUAN}

Pembelajaran IPA merupakan pembelajaran dengan situasi yang alami dari dunia nyata siswa, sehingga siswa terdorong membuat hubungan cabang IPA dengan pengetahuan sebelumnya yang telah dimiliki. Pembelajaran IPA menekankan pada hubungan materi pembelajaran yang sedang dipelajari dengan pengalaman keseharian siswa yang sesuai dengan lingkungan alam. Pembelajaran IPA mengarah pada pembelajaran bermakna yang memungkinkan siswa menerapkan konsep-konsep sains menggunakan pendekatan saintifik (Rahmatiah, 2014).
Pembelajaran IPA dengan menggunakan pendekatan saintifik adalah pembelajaran yang memberikan pengalaman secara langsung baik menggunakan observasi maupun eksperimen, sehingga data yang diperoleh selain valid juga dapat dipertanggungjawabkan (Sujarwanta, 2012). Hakikat IPA mempersyaratkan untuk menggunakan pendekatan saintifik dalam setiap tahapan pembelajaran yang dilakukan melalui proses mengamati, menanya, mencoba, mengasosiasi dan mengkomunikasikan. Salah satu tujuan pembelajaran dengan pendekatan saintifik adalah untuk meningkatkan kemampuan intelek 
siswa, khususnya kemampuan berpikir kritis (critical thinking skill) yang merupakan karakteristik dalam pembelajaran pada abad ke-21 untuk kepentingan di masa depan (Rosana, 2014).

Salah satu kompetensi yang perlu dimiliki seorang guru dalam melaksanakan pembelajaran kepada siswa adalah mengembangkan bahan ajar. Pengembangan bahan ajar penting dilakukan guru supaya pembelajaran lebih efektif, efisien, dan tidak melenceng dari kompetensi yang ingin dicapai (Sungkono, 2003). Hal tersebut sesuai dengan PP nomor 19 tahun 2005 Pasal 20, diisyaratkan bahwa guru diharapkan dapat mengembangkan materi pembelajaran, yang mensyaratkan bagi pendidik pada satuan pendidikan untuk mengembangkan rencana pelaksanaan pembelajaran (RPP). Salah satu elemen dalam RPP adalah sumber belajar, dengan demikian guru diharapkan dapat mengembangkan bahan ajar sebagai salah satu sumber belajar (Depdiknas, 2008).

Modul merupakan salah satu media pembelajaran yang dapat digunakan siswa sebagai sumber belajar dalam pembelajaran IPA. Pada dasarnya modul adalah sebuah bahan ajar yang disusun secara sistematis dengan menggunakan bahasa yang mudah dipahami siswa sesuai dengan tingkat pengetahuan dan usianya supaya siswa dapat belajar secara mandiri dengan bimbingan yang minimal dari guru. Pembelajaran dengan menggunakan modul dapat membuat siswa mengukur sendiri tingkat penguasaannya terhadap materi yang dibahas pada setiap satu satuan modul, sehingga jika telah menguasainya maka siswa dapat melanjutkan pada tingkat berikutnya. Sebaliknya jika siswa belum mampu maka siswa akan diminta untuk mengulangi dan mempelajarinya kembali (Prastowo, 2014). Modul yang baik tidak hanya menarik tetapi juga harus dapat menumbuhkan rasa ingin tahu siswa terhadap ilmu yang dipelajari. Apabila siswa memiliki rasa ingin tahu yang tinggi terhadap materi pembelajaran, maka siswa akan lebih termotivasi untuk belajar sehingga dapat meningkatkan kemampuan berpikir tingkat tinggi dan hasil belajar siswa.

\section{METODE PENELITIAN}

Penelitian ini menggunakan penelitian Meta-Analisis. Sebagai bagian dari penelitian, meta-analis merupakan kajian atas sejumlah hasil penelitian dalam masalah yang sejenis. Teknik pengumpulan data dilakukan dengan cara mendokumentasikan artikel jurnal baik nasional amupun internasional yang berhubungan dengan modul dan saintifik melalui internet. Penelitian meta-analisis ini bertujuan untuk melihat tingkat validitas dan praktikalitas pada masing-masing data yang dikumpulkan. Adapun populasi dalam penelitian ini adalah semua dokumen tertulis mengenai penelitian pendidikan yang membahas emodul/modul dengan menggunakan pendekatan saintifik. Sampel yang digunakan adalah 20 artikel jurnal.

Salah satu syarat meta analisis adalah pengkodean (coding) yang bertujuan mempermudah dalam mengumpulkan dan menganalisis data. Maka, variabel-variabel yang dipakai untuk pemberian kode dan menghasilkan informasi yang diperlukan dalam menghitung besar kevalidan dari pengembangan modul menggunakan pendekatan saintifik adalah nama peneliti dan tahun penelitian, judul penelitian, persentase validitas dan praktikalitas.

Dalam melakukan tabulasi data, mengikuti tahapan sebagai berikut : (1) mengidetifikasi variabel penelitian; (2) mengidentifikasi rerata validitas isi pada setiap artikel yang dianalisis/ subjek penelitian; (3) mengidentifikasi rerata validitas penyajian pada setiap artikel yang dianalisis/ subjek penelitian; (4) mengidentifikasi rerata validitas bahasa untuk setiap artikel yang dianalisis/ subjek penelitian, (5) mengidentifikasi rerata validitas grafis untuk setiap artikel yang dianalisis/ subjek penelitian;(6) mengidentifikasi rerata praktilaitas untuk setiap artikel atau subjek penelitian, (7)meng identifikasi rerata praktikalitas pendidik setiap artikel atau 
subjek penelitian; (8) menghitungan rerata akhir dari empat komponen validitas dan rerata akhir praktikalitas .

Untuk menghitung rerata persentase validitas dan praktikalitas dapat menggunakan rumus sebagai berikut:

$$
\text { Persentase }=\frac{\mathrm{X}}{\mathrm{Y}}
$$

Keterangan $\mathrm{X}=$ jumlah persentase

$$
\mathrm{Y}=\text { banyak data }
$$

Tabel 1. Kategori Validitas Produk

\begin{tabular}{|c|c|}
\hline Interval & Kategori \\
\hline$\geq 0,61-1,00$ & Valid \\
\hline$<0,61$ & Tidak Valid \\
\hline
\end{tabular}

(Azwar, 2015)

Valid atau sahih atau tepat artinya instrumen yang dibangun mampu mengukur apa yang hendak diukur. Ada 4 aspek yang divalidasi oleh masing-masing ahli yaituaspek validitas isi, validitas penyajian, validitas kebahasaan, validitas kegrafisan. Saran dan masukan dari validator digunakan sebagai bahan penyempurnaan terhadap instrumen yang sedang dibangun agar produk yang dihasilkan valid. Penelitian ini melihat validitas yang sudah dilakukan oleh peneliti yang menjadi subjek penelitian. Hasil validitas

Tabel 3. Karakteristik 20 artikel penelitian yang sesuai dengan topik yang dianalisis

\begin{tabular}{|c|c|c|c|c|c|c|c|}
\hline \multirow{2}{*}{ No } & \multirow{2}{*}{ Judul Artikel } & \multicolumn{4}{|c|}{ Validitas } & \multicolumn{2}{|c|}{ Praktis } \\
\hline & & I & $P$ & B & $\mathrm{G}$ & $\mathrm{Gr}$ & $S$ \\
\hline 1 & $\begin{array}{l}\text { Pengembangan } \\
\text { pembelajaran zat adiktif dan } \\
\text { psikotropika berbasis scientific } \\
\text { approach dengan crossword } \\
\text { puzzle }\end{array}$ & 0,91 & 0,85 & 0,83 & 0,81 & 0,93 & 0,81 \\
\hline 2 & $\begin{array}{lrr}\text { Pengembangan Modul } & \text { IPA } \\
\text { Berbasis Saintifik Pada } & \text { Tema } \\
\text { Polusi } & \text { Udara } & \text { Untuk } \\
\text { Meningkatkan Motivasi } & \text { Belajar } \\
\text { Dan Keterampilan Proses } & \text { Sains } \\
\text { (KPS) Siswa Di SMP/MTs Kelas } \\
\text { VII }\end{array}$ & 0,94 & 0,97 & 0,89 & - & 0,89 & 0,93 \\
\hline 3 & $\begin{array}{l}\text { Validitas Dan Praktikalitas E- } \\
\text { Modul Sistem Koloid Berbasis } \\
\text { Pendekatan Saintifik }\end{array}$ & 0,81 & 0,83 & 0,85 & 0,83 & 0,92 & 0,87 \\
\hline 4 & $\begin{array}{l}\text { Pengembangan Modul Berbasis } \\
\text { Saintifik Model Discovery } \\
\text { Learning Pada Materi Sistem } \\
\text { Ekskresi Manusia Untuk Siswa }\end{array}$ & 0,94 & 0,97 & 0,98 & 0,93 & 0,99 & 0,99 \\
\hline
\end{tabular}
dan diteliti tersebut dianalisis dan kemudian didapatkan hasil yang sesuai dengan tujuan penelitian.

$$
\text { Untuk praktikalitas dapat }
$$
dibandingkan dengan kategori sebagaimana pada tabel berikut:

Tabel 2. Kategori Praktikalitas Produk

\begin{tabular}{|l|l|}
\hline \multicolumn{1}{|c|}{ Interval } & \multicolumn{1}{c|}{ Kategori } \\
\hline $0,81-1,00$ & Sangat Tinggi \\
\hline $0,61-0,80$ & Tinggi \\
\hline $0,41-0,60$ & Sedang \\
\hline $0,21-0,40$ & Rendah \\
\hline $0,01-0,20$ & Sangat Rendah \\
\hline 0,00 & Tidak Praktis \\
\hline
\end{tabular}

(Boslaugh, 2008)

Praktikalitas

merupakan

kemudahan produk yang dihasilkan pada saat digunakan. Praktikalitas dapat diujikan pada siswa dan guru. Hasil praktikalitas produk dari guru dan siswa menjadi variabel yang dinalisis dan diteliti. Hasil yang didapat kemudian disesuaikan dengan tujuan penelitian.

\section{HASIL DAN PEMBAHASAN}

Berdasarkan analisis yang dilakukan terhadap 20 artikel dari jurnal nasional dan internasional yang dilakukan, ditemukan karkteristik masing-masing artikel sebagaimana pada tabel berikut. 


\begin{tabular}{|c|c|c|c|c|c|c|c|}
\hline & $\begin{array}{l}\text { Kelas XI SMA Negeri } 1 \text { Lembah } \\
\text { Gumanti }\end{array}$ & & & & & & \\
\hline 5 & $\begin{array}{l}\text { Pengembangan Modul } \\
\text { Keanekaragaman Hayati Berbasis } \\
\text { Pendekatan Saintifik Untuk Siswa } \\
\text { Kelas X SMA/MA Sederajat }\end{array}$ & 0,93 & 0,94 & 0,97 & 0,87 & 0,87 & 0.80 \\
\hline 6 & $\begin{array}{l}\text { Validitas dan Praktikalitas Modul } \\
\text { Larutan Penyangga Berbasis } \\
\text { Pendekatan Saintifik dengan } \\
\text { Menerapkan Teknik Probing dan } \\
\text { Promting untuk Kelas XI SMA/ } \\
\text { MA }\end{array}$ & 0,91 & 0,95 & 0,94 & 0,94 & 0,87 & 0,73 \\
\hline 7 & $\begin{array}{l}\text { Pengembangan Modul Berbasis } \\
\text { Pendekatan Saintifik Disertai } \\
\text { Glosarium Tentang Materi Sistem } \\
\text { Ekskresi Pada Manusia Untuk } \\
\text { Peserta Didik Kelas VIII }\end{array}$ & 0,87 & 0,88 & 0,86 & 0,91 & 0,89 & 0,85 \\
\hline 8 & \begin{tabular}{lcr}
\multicolumn{2}{l}{ Pengembangan } & Modul \\
Pembelajaran & Biologi & Berbasis \\
Pendekatan & Saintifik & Untuk \\
Meningkatkan & Hasil & Belajar \\
Siswa & & \\
\end{tabular} & 0,81 & 0,81 & 0,86 & 0,83 & 0,84 & 0,89 \\
\hline 9 & 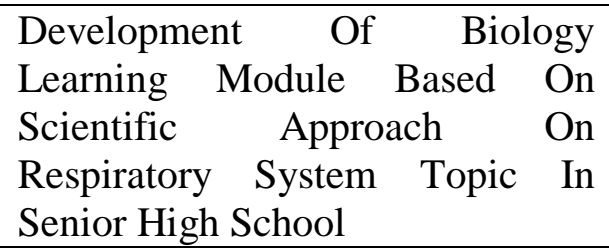 & 0,85 & 0,86 & 0,86 & 0,85 & 0,89 & 0,86 \\
\hline 10 & $\begin{array}{l}\text { Developing Scientific Approach } \\
\text { Based Learning Module In } \\
\text { Plantae Concept }\end{array}$ & 0,87 & 0,89 & 0,83 & 0,88 & 0,87 & 0,95 \\
\hline 11 & \begin{tabular}{lr}
\multicolumn{3}{l}{ Validitas dan Praktikalitas Modul } \\
Hukum-Hukum Dasar & Kimia \\
Berbasis Pendekatan Saintifik \\
dengan Menerapkan Teknik \\
Probing Prompting untuk Siswa \\
Kelas X SMA/MA
\end{tabular} & 0,87 & 0,89 & 0,95 & 0,84 & 0,90 & 0,90 \\
\hline 12 & $\begin{array}{l}\text { Pengembangan Modul Laju } \\
\text { Reaksi Berbasis Pendekatan } \\
\text { Saintifik Dengan Pertanyaan } \\
\text { Probing Prompting } \\
\text { XI SMtuk Kelas } \\
\end{array}$ & 0,88 & 0,91 & 0,94 & 0,91 & 0,88 & 0,88 \\
\hline 13 & $\begin{array}{l}\text { Pengembangan Modul Fisika } \\
\text { Berbasis Scientific Approach } \\
\text { Untuk } \\
\text { Keterampilan Proses Sains Siswa }\end{array}$ & 0,63 & 0,87 & 0,75 & 0,77 & 0,77 & 0,65 \\
\hline 14 & $\begin{array}{l}\text { Pengembangan Modul Berbasis } \\
\text { Pendekatan Saintifik Pada Mata } \\
\text { Pelajaran IPA Di Smp }\end{array}$ & 0,85 & 0,85 & - & 0,87 & 0,85 & 0,89 \\
\hline 15 & $\begin{array}{l}\text { Pengembangan Modul IPA } \\
\text { Berbasis Saintifik Pada Materi } \\
\text { Interaksi Mahluk Hidup Dengan } \\
\text { Lingkungan Untuk Meningkatkan } \\
\text { Kemampuan Berpikir Kritis Dan } \\
\text { Hasil Belajar Siswa Kelas VII } \\
\text { SMP }\end{array}$ & 0,93 & 0,82 & 0,92 & 0,84 & 0,62 & 0,64 \\
\hline
\end{tabular}




\begin{tabular}{|l|l|l|l|l|l|l|l|}
\hline 16 & $\begin{array}{l}\text { Pengembangan Modul Fisika } \\
\text { Materi Optik Dengan Pendekatan } \\
\text { Saintifik Berbasis Fenomena } \\
\text { Alam Untuk Meningkatkan } \\
\text { Efektivitas Belajar Siswa SMA }\end{array}$ & 0,94 & 0,89 & 0,89 & - & 0,90 & 0,89 \\
\hline 17 & $\begin{array}{l}\text { Pengembangan Modul } \\
\text { Kesetimbangan Kimia Berbasis } \\
\text { Pendekatan Saintifik Untuk Kelas } \\
\text { XI SMA/MA }\end{array}$ & 0,87 & 0,83 & 0,81 & 0,84 & 0,84 & 0,87 \\
\hline 18 & $\begin{array}{l}\text { Pengembangan E-Modul } \\
\text { Keseimbangan Kimia Berbasis } \\
\text { Pendekatan Saintifik Untuk Kelas } \\
\text { XI SMA/MA }\end{array}$ & 0,79 & 0,83 & 0,82 & 0,80 & 0,85 & 0,84 \\
\hline 19 & $\begin{array}{l}\text { Pengembangan Bahan Ajar } \\
\text { Berdasarkan Pendekatan Saintfik } \\
\text { Untuk Siswa Smp Negeri 2 } \\
\text { Sungai Limau }\end{array}$ & 0,79 & 0,82 & 0,75 & 0,87 & 0,86 & 0,92 \\
\hline 20 & $\begin{array}{l}\text { Development of Module Based on } \\
\text { Scientific Contextual Additives } \\
\text { Material to Increase Learning } \\
\text { Outcomes and Science Process } \\
\text { Skills in Junior High School }\end{array}$ & 0,86 & 0,94 & 0,85 & - & 0,86 & 0,87 \\
\hline
\end{tabular}

Keterangan: I = Isi; P = Penyajian; B = Bahasa; $\mathrm{G}$ = Grafis; Gr = Guru; S = Siswa

Pada Tabel 3 di atas bisa dilihat bahwa analisis dan kajian terhadap 20 artikel ada empat aspek validitas yaitu validitas isi, penyajian, bahasa, grafis dan dua aspek praktikalitas yaitu guru dan siswa yang menjadi kajian pada penelitian ini yang sudah dikembangkan oleh peneliti sebelumnya terkait modul IPA berbasis pendekatan saintifik. Sukardi (2011) Validitas merupakan penilaian terhadap rancangan suatu produk. Aspek penilaian pada lembar validitas dibagi menjadi beberapa komponen yang terdiri dari komponen isi, komponen penyajian, komponen kebahasaan dan komponen kegrafikan (Depdiknas, 2008) . Sugiyono (2010), validasi terhadap produk pengembangan dapat dilakukan oleh beberapa ahli atau pakar yang mampu menilai kelemahan dan kelebihan suatu produk. Berdasarkan yang menjadi sabjek dalam penelitian ini, maka ditemukan validitas dan praktikalitas setiap aspek dari produk berupa modul IPA yang dikembangak, sebagaimana berikut:

\section{Validitas}

a. Validitas Isi

Validasi ahli yang dilakukan akan menghasilkan validtas produk yang dikembangkan. Validitas artinya ketapatan atau kesesuaian dari isi modul yang disusun atau dikonstruksi oleh pengembang atau peneliti dengan pembelajaran yang seharusnya diinginkan oleh kurikulum. Berdasarkan analisis terhadap validitas isi dari 20 artikel yang dikaji, diperoleh hasil sebagai mana pada grafik dibawah ini:

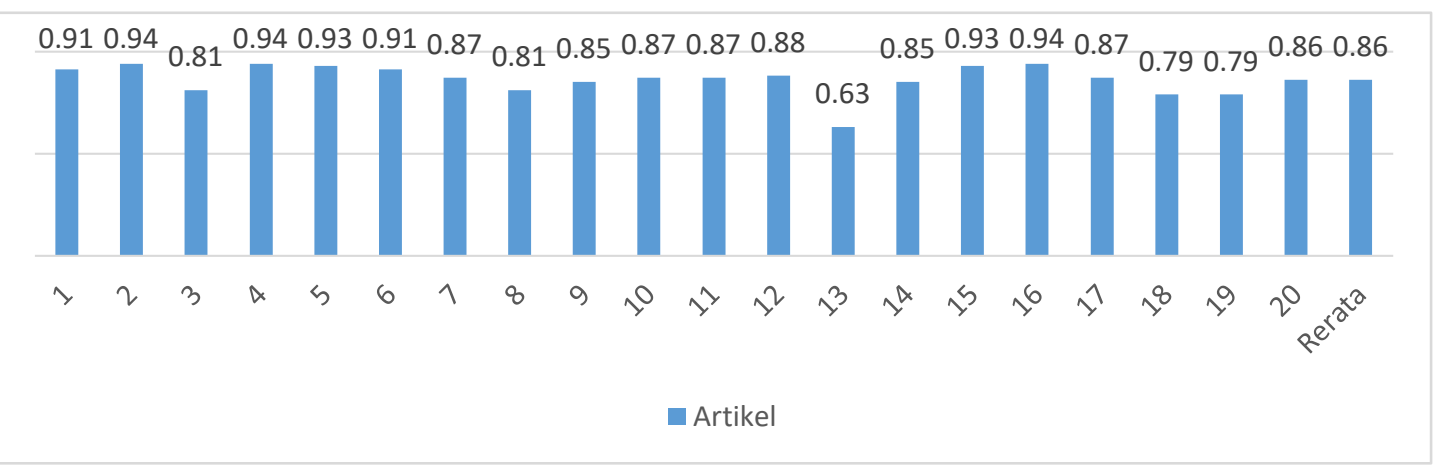

Gambar 1. Validitas Isi Modul IPA 
Pada Gambar 1 di atas dapat diketahui bahwa dari 20 artikel yang dianalisis ditemukan rata-rata validitas isi dari produk modul yang dikembangkan oleh peneliti yang paling rendah adalah atikel 13 dengan skor 0,63 dan validitas tertinggi adalah artikel 2 dan 4 masing 0,94. Rata-rata validitas isi modul IPA berbasis saintifik yang dikembangkan oleh peneliti dari 20 artikel yang dianalisis adalah 0,86 dengan kategori valid. Hal ini menunjukkan bahwa uraian isi yang digunakan pada modul sesuai dengan kompetensi dasar, indikator, tujuan serta pokok-pokok kegiatan yang diperlukan. Ramayan \& Defianto (2019) menemukan isi modul yang valid akan bermnafaat untuk menambah wawasan siswa dan tidak bertentangan dengan nilai-nilai moral ada dalam masyarakat. Oleh sebab itu, dari segi isi modul layak digunakan untuk siswa.

Isi modul yang sudah valid menunjukkan kesesuaian antara latihanlatihan yang terdapat dalam modul dengan tuntutan materi yang harus diajarkan. Modul yang dirancang harus sesuai dengan tuntutan kurikulum serta karakteristik materi ajar. (Suciana dan Ellizar, 2019). Sejalan dengan itu Depdiknas (2008), aspek komponen isi meliputi kesesuaian materi yang terdapat dalam modul dengan kompetensi inti dan kompetensi dasar tujuan pembelajaran yang ingin dicapai dan materi yang diberikan sesuai dengan kemampuan siswa. Pertanyaan yang diajukan dapat memotivasi, membimbing dan menuntun siswa dalam menemukan konsep.

Natalina et.al (2016), validnya kelayakan isi karena isi modul telah sesuai dengan aspek aspek pada kriteria kelayakan isi yang meliputi kesesuaian dengan kebutuhan siswa, kesesuaian dengan kebutuhan bahan ajar, kebenaran substansi konsep materi dari aspek keilmuan, materi yang disampaikan jelas dan sistematis, materi yang disajikan membantu siswa dalam memahami konsep, keterkaitan contoh materi dengan kondisi yang ada di lingkungan sekitar, kebenaran kunci jawaban yang disajikan, manfaat untuk penambahan wawasan pengetahuan, kesesuaian dengan nilai-nilai, moralitas dan sosial, setiap kegiatan belajar pada materi di dalam modul sudah mengarahkan siswa pada pendekatan saintifik yang terdiri dari 5 langkah yaitu mengamati, menanya, mencoba, menalar dan mengkomunikasikan.

b. Validitas Penyajian

Kualitas penyajian produk yang dikembangkan perlu divalidasi, hasil dari validasi ahli tersebut disebut validitas penyajian. Validitas penyajian dari hasil analisis terhadap 20 artikel yang menjadi subjek dalam penelitian ini dapat dilaihat pada gambar berikut:

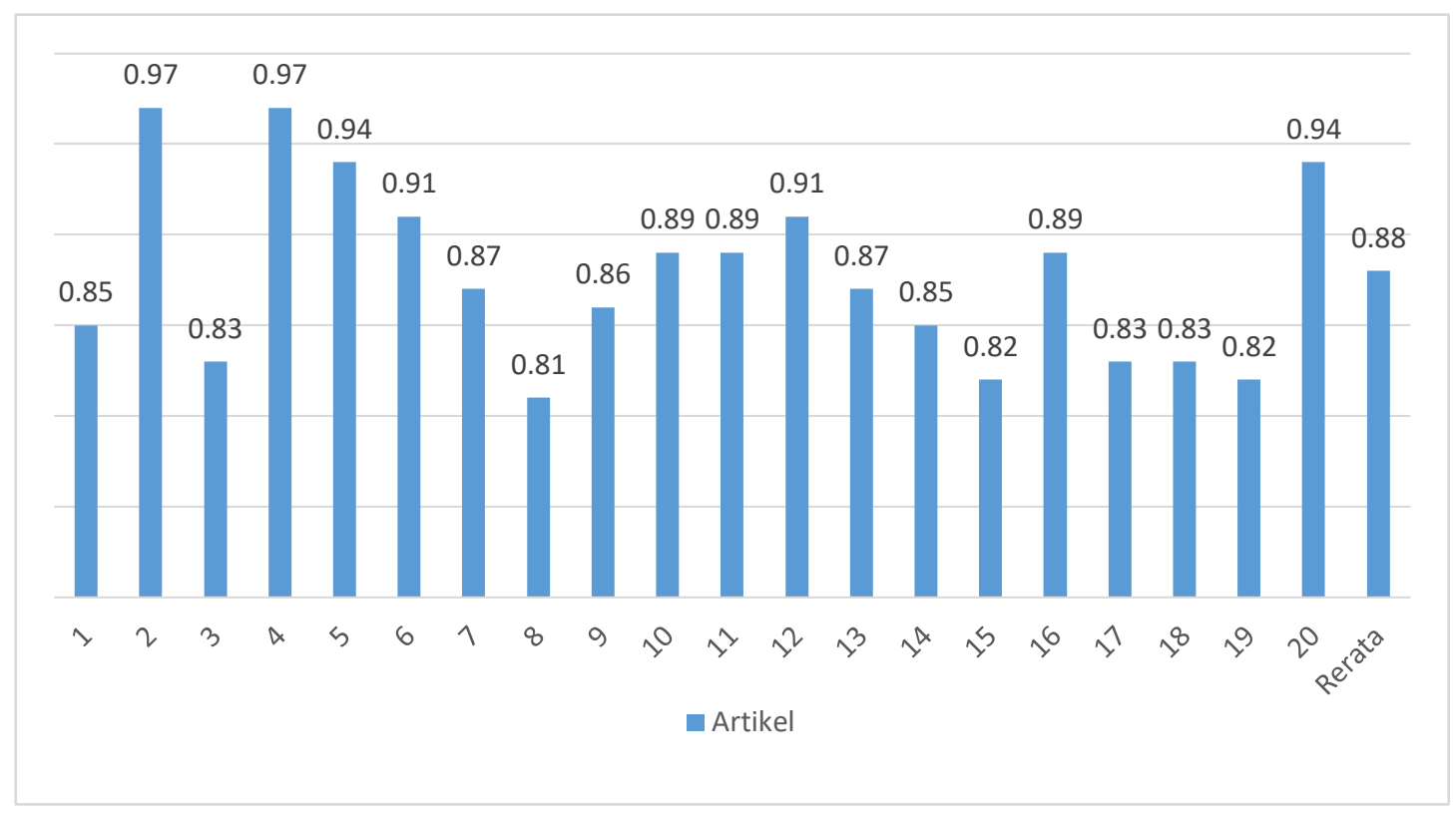

Gambar 2. Validitas Penyajian Modul IPA 
Gambar 2 menujukkan bahwa validitas penyajian terendah ada pada artikel 8 yaitu 0,81 dan tertinggi yaitu artikel 2 dan 4 dengan masing-masing 0,97 dan rata-rata validitas penyajian dari 20 artikel adalah 0,88 dengan kategori valid. Ini artinya, modul IPA berbasis saintifik telah dikembangkan dan dibuat sesuai dengan indikator dan tujuan pembelajaran yang telah dirumuskan. Modul disajikan berdasarkan tahapan pendekatan saintifik. Pada tahapan tersebut terdapat pertanyaan-pertanyaan yang menggali dan menuntun sehingga terjadi proses berfikir yang mengaitkan pengetahuan baru peserta didik dengan pengetahuan lama yang dimilikinya, sehingga peserta didik terlibat aktif dalam proses pembelajaran. Ramayani dan Delfianto (2019), panyajian modul berbasis saintifik yang sudah valid dapat diartikan bahwa modul tersebut telah disajikan sesuai dengan prisip modul berdasarkan penedekatan saintifik, yaitu mengamati, menemukan, mengasosiasi, dan mengkomunikasikan.

Jannah dan Elizar (2018) menyatakan bahwa kategori valid pada kelayakan penyajian menunjukkan bahwa bahwa modul yang dihasilkan telah tersusun secara sistematis sesuai dengan unsur modul pembelajaran. Selain itu, modul IPA yang dihasilkan sudah memuat aspek komponen penyajian yang sesuai dengan Depdiknas yang meliputi kejelasan tujuan yang ingin dicapai, urutan penyajian, dan sistematikan tahapan saintifik yang diterapkan dalam penyampaian materinya. Karakteristik penting dalam modul harus memuat tujuan pembelajaran yang jelas dan dapat menggambarkan pencapaian standar kompetensi dan kompetensi dasar.

c. Validitas Bahasa

Untuk mengetahui kualitas bahasa yang digunakan dalam produk yang dikembangkan apakah sesuai dengan EYD atau tidak, maka perlu dilakukan validasi ahli. Dari proses validasi akan diketahui validitas bahasa tersebut. Hasil analisis terhadap 20 artikel subjek penelitian ditemukan validitas bahasa yang digunakan sebagaimana pada gambar berikut:

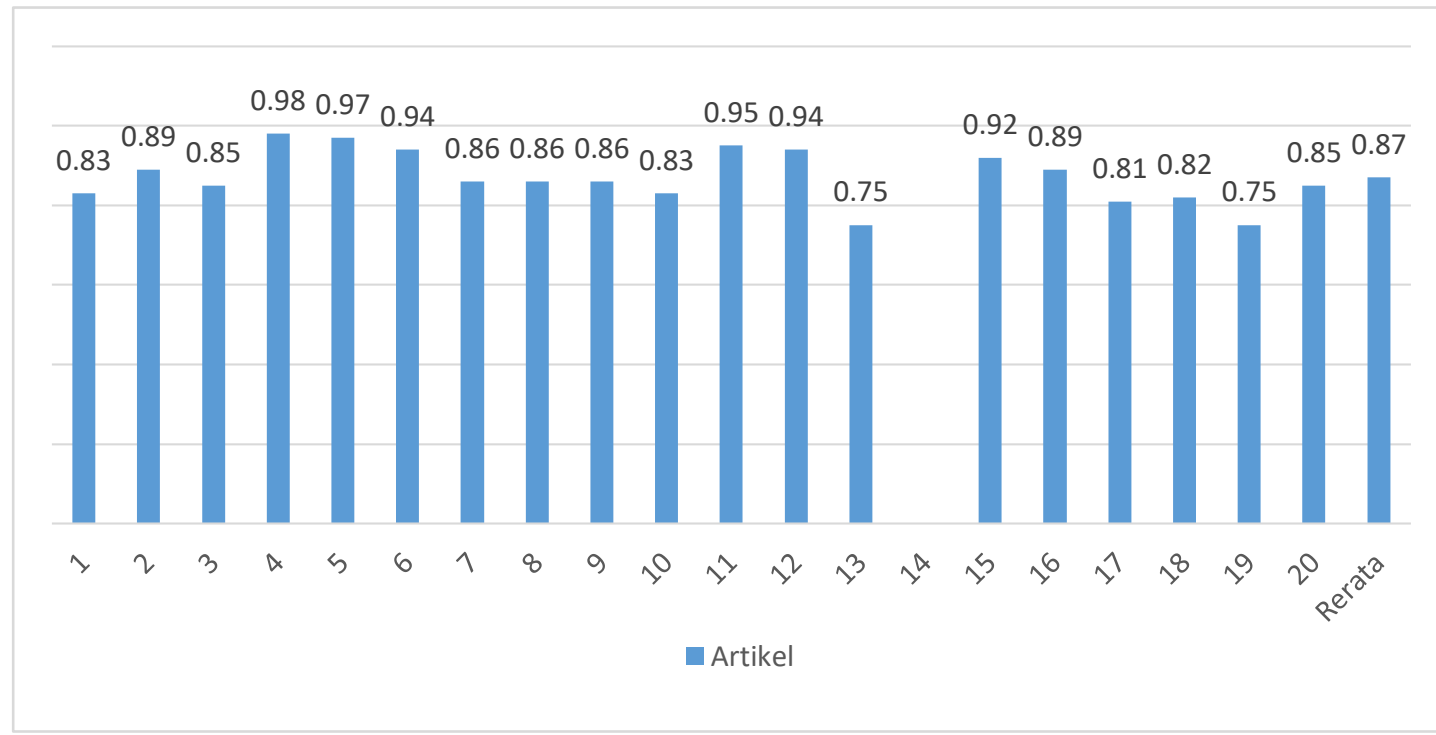

Gambar 3. Validitas Bahasa Modul IPA

Berdasarkan Gambar 3 dapat kita ketahui berdasarkan aspek bahasa, 20 artikel yang dianalisis menunjukkan kategori valid. Rerata validitas bahasa dari 20 artikel tersebut adalah 0,87 denagn aktegori valid. Hal ini menunjukkan bahawa bahasa yang digunakan pada modul IPA berbasis saintifik yang dihasilkan peneliti sudah sesuai dengan EYD dan komunikatif. Jannah dan Elizar (2018) menyatakan bahwa validitas bahasa yang sangat tinggi menunjukkan modul sudah menggunakan bahasa komunikatif dan menggunakan bahasa yang mudah 
dipahami serta konsisten dalam pendekatan saintifik dnegan menerapkan penggunaan simbol/ lambang.

\section{d. Validitas Grafis}

Validasi grafis diperlukan untuk mengetahui kualitas atau kesesuaian huruf baik jenis ataupun ukuran serta penggunaan gambar menarik atau tidaknya. Validasi bertujuan untuk mengungkapkan tingkat validitas/ kelayakan modul IPA berbasis

yang dikembangkan. Validasi grafis dilakukan untuk mendapatkan saran dan kritikan dari validator/orang yang ahli dibidangnya dalam memberikan masukan terhadap modul . yang dihasilkanHasil validitas grafis dari 20 artikel yang dianalisis dapat diketahui sebagaimana pada gambar berikut:

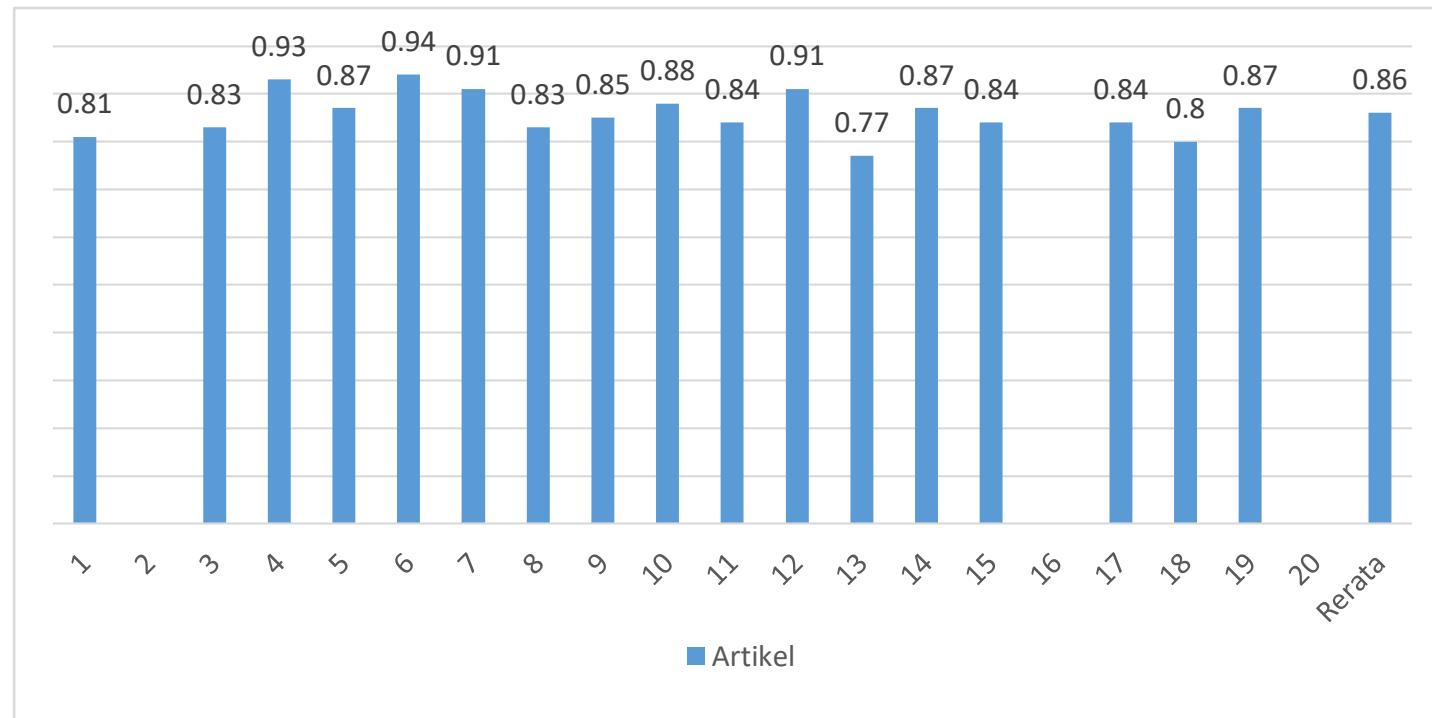

Gambar 4. Validitas Grafis Modul IPA

Rata-rata validitas dari aspek kegrafisan dari modul IPA berbasis saintifik yang diekembangkan peneliti adalah 0,86 dengan kategori valid. Angka ini menunjukkan modul yang dikembangkan memiliki gambar, ilustrasi, huruf, tata letak, desain tampilan dan desain sampul yang jelas secara keseluruhan dan menarik. Nasution (1982), Modul yang dibuat semenarik mungkin dan disusun dengan cermat dapat memudahkan siswa untuk belajar menguasai bahan pelajaran. Aspek dari komponen kegrafikan meliputi gambar atau foto yang disajikan pada modul dapat diamati dengan jelas, jenis dan ukuran (font) huruf yang digunakan tepat dan jelas terbaca, tata letak (lay out) teratur dan warna yang digunakan menarik serta desain modul (cover, gambar) menarik.

\section{Praktikalitas}

Pada suatu produk pengembangan dari suatu penelitian harus dilakukan uji terhadap praktikalitasnya. Uji praktikalitas dapat diberikan kepada guru dan siswa. Hasil uji praktikalitas yang dikembangkan oleh peneliti pada artikel yang dianalisis dalam penelitian ini dapat dilihat dari dua aspek yaitu praktikalitas guru dan praktikalitas siswa.

a. Praktikalitas Guru

Praktikalitas guru maksudnya adalah tingkat kemudahan penggunaan produk yang dikembangkan peneliti oleh guru di kelas. Paraktikalitas guru dari 20 artikel yang dianalisis dapat dilihat pada gambar berikut: 


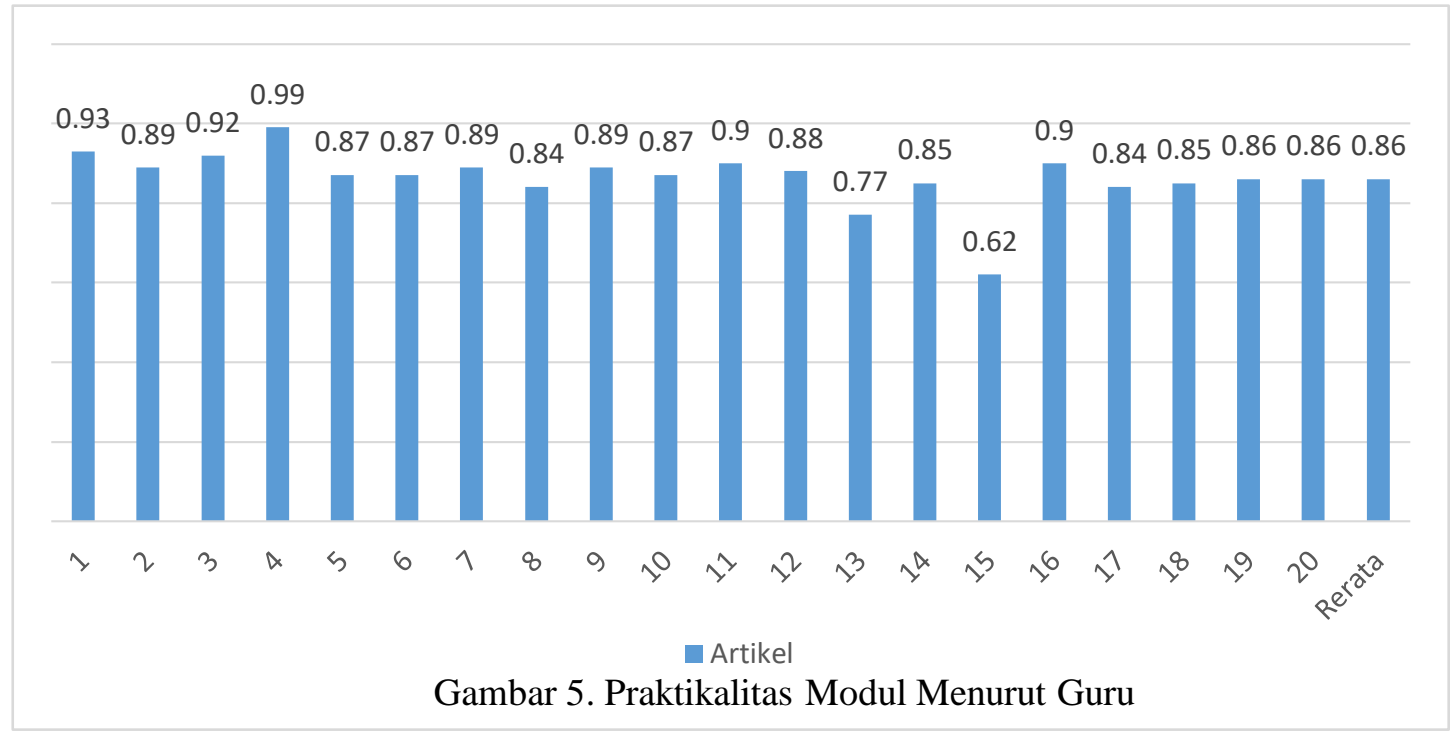

Gambar 5 menjelaskan semua peneliti melakukan uji praktikaltas guru terhadap produk yang dikembangkan. Artikel 4 menunjukkan praktikalitas tettinggi yaitu 0,99 sedangkan praktikalitas terendah artikel 15 yaitu 0,62 . Rata-rata praktikalitas guru terhadap modul IPA yang dikembangkan dari 20 artikel yang dianalisis adalah 0,86 dengan kategori praktikalitas sangat tinggi. Ini menunjukkan bahwa modul yang dikembangkan mudah digunakan oleh guru, mudah dipahami, sesuai dengan karater saintifik dan dapat digunakan berulang-ulang.

Arimadona dan Silvina (2019) rerata praktikalitas gru yang sangat tinggi menunjukkan bahwa modul yang dikembangkan masuk dalam kriteria sangat praktis. Dengan demikian modul yang dikembangkan untuk dapat membantu dan mempermudahkan guru dalam memfasilitasi pembelajaran yang berbasis pada pendekatan saintifik, modul IPA yang dikembangkan ini juga dapat memberikan manfaat untuk dapat mengefisienkan waktu dalam penyampaian materi pembelajaran.

b. Praktikalitas Siswa

Praktikalitas siswa maksudnya adalah tingkat kemudahan penggunaan produk yang dikembangkan peneliti oleh siswa di kelas. Paraktikalitas siswa dari 20 artikel yang dianalisis dapat dilihat pada gambar berikut:

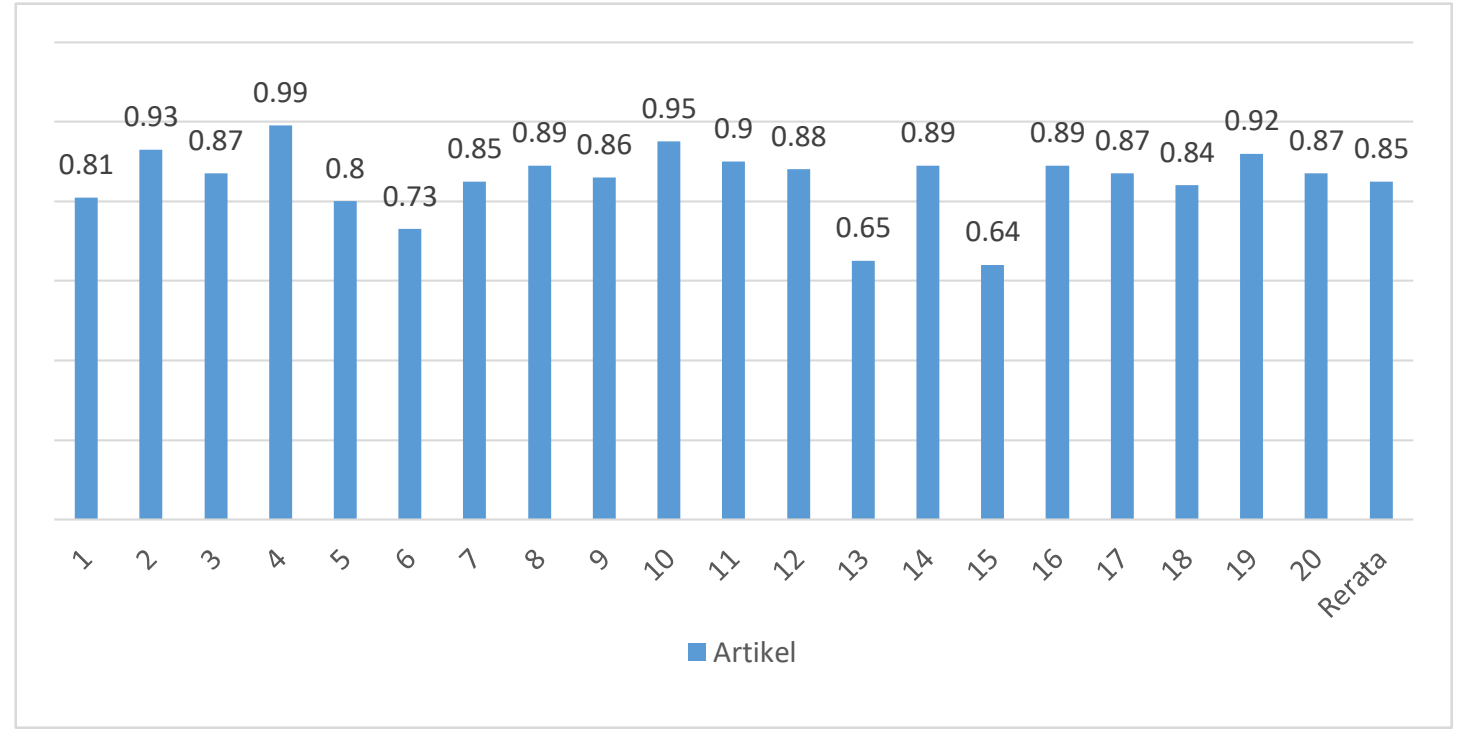

Gambar 6. Praktikalitas Modul Menurut Siswa 
Gambar 6 menunjukkan bahwa rerata praktikalitas oleh siswa yaitu sebesar 0,85 dan termasuk kriteria praktis. Hasil analisis praktikalitas modul oleh siswa menunjukkan bahwa secara keseluruhan modul pembelajaran IPA berbasis saintifik yang dikembangkan disenangi dan dapat menarik minat siswa untuk mengikuti pembelajaran.Sudirman dalam Djamarah dan Zain (2006), nilai-nilai praktis media pembelajaran dapat mengontrol dan mengatur waktu belajar siswa agar lebih efisien.

\section{KESIMPULAN}

Berdasarkan hasil meta-analisis dapat disimpulkan bahwa pengembangan modul berbasis saintifik pada pembelajaran IPA sudah memenuhi kategori valid dan praktis. Sehingga modul ini dapat digunakan oleh guru dan siswa dalam proses pembelajaran dalam rangka membantu peserta didik dalam memahami materi pembelajaran sehingga dapat meningkatkan hasil belajar.

\section{DAFTAR PUSTAKA}

Arimadona S \& Silvina R. (2019). Pengembangan Modul Pembelajaran Zat Adiktif Dan Psikotropika Berbasis Scientific Approach Dengan Crossword Puzzle. Jipva (Jurnal Pendidikan IPA Veteran). Volume 3 Nomor 1, 2019.

Agusti D., Rahmatan H., Sulastri. (2019). Pengembangan Modul Pembelajaran Sistem Reproduksi Berazaskan Al-Quran/Hadis Untuk Meningkatkan motivasi Dan Hasil Belajar Peserta Didik. EDUSAINS, 11(1), 2019, 132140.

Alwi A.M. (2018). Pengembangan Modul Berbasis Pendekatan Saintifik Pada Mata Pelajaran IPA Di SMP. Jurnal Teknologi Pendidikan dan Pembelajaran Tahun 5, Nomor 1 Juli 2018.

Asmiyunda.,Guspatni.,Azra～F. (2018). (Pengembangan

E-Modul
Keseimbangan Kimia Berbasis Pendekatan Saintifik Untuk Kelas XI SMA/MA. JEP Volume 2 Nomor 2 November 2018.

Aulia M dan Kosim K. (2017). Pengembangan Modul Fisika Materi Optik Dengan Pendekatan Saintifik Berbasis Fenomena Alam Untuk Meningkatkan Efektivitas Belajar Siswa SMA . Jurnal Pijar MIPA Vol 12 No 2.

Azwar, S. (2015). Reabilitas dan Validitas Edisi IV, Cetakan IV. Yogyakarta: Pustaka Pelajar.

Boslaugh, sarah, dan Watters P.A. (2008). Statistics in a Nutshell, a Desktop Quick Referance". United state of America: O’Reilley Media, Inc.

Departemen Pendidikan Nasional. 2008. Panduan Pengembangan Bahan Ajar. Jakarta: Departemen Pendidikan Nasional, Direktorat Jenderal Manajemen Pendidikan Dasar dan Menengah, Direktorat Pembinaan Sekolah Menengah Atas.

Dewi I.S. ,Sunarno W.,Dwiastuti S. (2019). Pengembangan Modul IPA Berbasis Saintifik Pada Materi Interaksi Mahluk Hidup Dengan Lingkungan Untuk Meningkatkan Kemampuan Berpikir Kritis Dan Hasil Belajar Siswa Kelas VII SMP. INKUIRI: Jurnal Pendidikan IPA Vol. 8, No. 2, 2019 (hal 186197).

Djamarah, B.S dan A. Zain. (2010). Strategi Belajar Mengajar. Jakarta: Rineka Cipta.

Ernica S.Y. dan Hardeli. (2019). Validitas Dan Praktikalitas EModul Sistem Koloid Berbasis Pendekatan Saintifik. Ranah Research Journal of Multidisiplinary Research and Depelopment.

Jannah W dan Elizar. (2018). Validitas dan Praktikalitas Modul Larutan 
Penyangga Berbasis Pendekatan Saintifik dengan Menerapkan Teknik Probing dan Promting untuk Kelas XI SMA/ MA. Menara Ilmu Vol. XII. No.12, oktober 2018

Kliyanti S.M.,Nengsih R., Yulianti E. (2018). Pengembangan Modul Keanekaragaman Hayati Berbasis Pendekatan Saintifik Untuk Siswa Kelas X SMA/MA Sederajat . Biocolony Vol. 1 No. 2, Desember 2018. Hal: 34-39.

Kurniawan G., Azrita., Muhar N. (2015). Pengembangan Modul Berbasis Saintifik Model Discovery Learning Pada Materi Sistem Ekskresi Manusia Untuk Siswa Kelas XI SMA Negeri 1 Lembah Gumanti. Jurnal Fakultas Keguruan dan Ilmu Pendidikan Vol 4 No 5.

Marera A. (2019). Development Of Biology Learning Module Based On Scientific Approach On Respiratory System Topic In Senior High School. Jurnal AlAhya Volume 1 Nomor 3 Oktober 2019.

Muhafid E.A., Suparmi \& Sunarno W. (2017). Pengembangan Modul Ipa Berbasis Saintifik Pada Tema Polusi Udara Untuk Meningkatkan Motivasi Belajar Dan Keterampilan Proses Sains (KPS) Siswa Di SMP/MTs Kelas VIII. Jurnal Inkuiri ISSN: 22527893, Vol. 6, No. 2, (hal 83-96)

Natalina M.,Syafi'i.,W.,Heryen S. (2016). Pengembangan Modul Pembelajaran IPA Biologi Berorientasi Pendekatan Saintifik Untuk Meningkatkan Kemampuan Berpikir Kritis Pada Materi Struktur Tumbuhan. Jurnal Biogenesis Vol. 13 (1): $141-148,2016$.

Prawita W.,Prayitno B.A.,, Sugiyarto. (2019). Effectiveness of a Generative Learning-Based Biology Module to Improve the
Analytical Thinking Skills of the Students with High and Low Reading Motivation. International Journal of Instruction. January 2019 . Vol.12, No.1.

Prastowo, A. (2014). Pengembangan Bahan Ajar Tematik Tinjauan Teoritis dan Praktik. Jakarta. Kencana Prenadamedia Group.Purwanto. 2011. Evaluasi Hasil Belajar. Yogyakarta: Pustaka Pelajar.

Rahmatiah. (2014). Mengasah Kreativitas dengan IPA Terpadu. Sulawesi Selatan: Artikel EBuletin LPMP Sulsel ISSN 2355- 3189.

Rosana, D. (2014). Pendekatan Saintifik dalam Pembelajaran IPA Secara Terpadu. Yogyakarta: Universitas Negeri Yogyakarta.

Sari Y.P and Gazali F. (2019). Validitas dan Praktikalitas Modul HukumHukum Dasar Kimia Berbasis Pendekatan Saintifik dengan Menerapkan Teknik Probing Prompting untuk Siswa Kelas X SMA/MA. Edukimia Journal eISSN: 2502-6399.

Sapitri D., Ardi.,Leilani I. (2017). Pengembangan Modul Berbasis Pendekatan Saintifik Disertai Glosarium Tentang Materi Sistem Ekskresi Pada Manusia Untuk Peserta Didik Kelas VIII. Journal Biosains Volume 1 Nomor 2017.

Setiyadi M.W., Ismail.,Gani A.H.(2017). Pengembangan Modul Pembelajaran Biologi Berbasis Pendekatan Saintifik Untuk Meningkatkan Hasil Belajar Siswa. Journal of Educational Science and Technology Volume 3 Nomor 2 Agustus 2017 Hal. 102- 112 .

Sumiati E.,,Septian D., Faizah F. (2018). Pengembangan Modul Fisika Berbasis Scientific Approach Untuk Meningkatkan 
Keterampilan Proses Sains Siswa. Jurnal Pendidikan Fisika dan Keilmuan. Vol 4, No 2.

Suciana D dan Ellizar. (2019). Pengembangan Modul Laju Reaksi Berbasis Pendekatan Saintifik Dengan Pertanyaan Probing Prompting Untuk Kelas XI SMA/MA. Edukimia Vol 1.

Sukardi. 2011. Evaluasi Pendidikan, Prinsip, dan Operasionalnya. Yogyakarta: Bumi Aksara Nasution, S. 1982. Berbagai Pendekatan dalam Proses Belajar \& Mengajar. Jakarta: Bumi Aksara.

Sumiati E.,Septian D.,F. Faizah. (2018)..Pengembangan Modul Fisika Berbasis Scientific Approach Untuk Meningkatkan Keterampilan Proses Sains Siswa. Jurnal Pendidikan Fisika dan Keilmuan (JPFK), 4 (2), 2018, 75-88.

Sungkono.(2003). Pengembangan dan Pemanfaatan Bahan Ajar Modul Dalam Pembelajaran. Yogyakarta: Universitas Negeri Yogyakarta.

Yani A.,Tahmir S., Muhiddin. (2019). Developing Scientific Approach Based Learning Module In Plantae Concept. ResearchGate

Yerimadesi.,Bayharti.,Handayani

F.,Legi W.F. (2016).

Pengembangan Modul

Kesetimbangan Kimia Berbasis

Pendekatan Saintifik Untuk

Kelas XI SMA/MA. Journal of Sainstek. ISSN:2085-8019.

Published by Association of Mathematics Science Education and Technology State Institute of Islamic Studies (AMSET-IAIN) Batusangkar. 